\title{
Molecular evolution of the human SRPX2 gene that causes brain disorders of the Rolandic and Sylvian speech areas
} Barbara Royer ${ }^{1}$, Dinesh C Soares ${ }^{2}$, Paul N Barlow2 ${ }^{2}$, Ronald E Bontrop ${ }^{3}$, Patrice Roll ${ }^{1}$, Andrée Robaglia-Schlupp ${ }^{1}$, Antoine Blancher ${ }^{4}$, Anthony Levasseur ${ }^{5}$, Pierre Cau ${ }^{1}$, Pierre Pontarotti ${ }^{5}$ and Pierre Szepetowski*1

Address: 1INSERM UMR 491, Université de la Méditerranée, 13385 Marseille, Cedex 5, France, ${ }^{2}$ Edinburgh Biomolecular NMR Unit, The University of Edinburgh, Edinburgh EH9 3JJ, UK, ${ }^{3}$ Biomedical Primate Research Centre, 2280 GH Rijswijk, The Netherlands, ${ }^{4}$ LIGM, Université Paul Sabatier, 31403 Toulouse, Cedex 4, France and 5EA 3781, Université d'Aix-Marseille I, 13331 Marseille, Cedex 3, France

Email: Barbara Royer - barbara.royer@medecine.univ-mrs.fr; Dinesh C Soares - D.C.Soares@sms.ed.ac.uk;

Paul N Barlow - paul.barlow@ed.ac.uk; Ronald E Bontrop - bontrop@bprc.nl; Patrice Roll - patrice.roll@medecine.univ-mrs.fr;

Andrée Robaglia-Schlupp - robaglia@medecine.univ-mrs.fr; Antoine Blancher - blancher@easynet.fr; Anthony Levasseur - levassr@up.univmrs.fr; Pierre Cau - pierre.cau@medecine.univ-mrs.fr; Pierre Pontarotti - pierre.pontarotti@up.univ-mrs.fr;

Pierre Szepetowski* - szepetowski@medecine.univ-mrs.fr

* Corresponding author

Published: 18 October 2007

BMC Genetics 2007, 8:72 doi:10.1186/147/-2156-8-72
Received: 29 March 2007

Accepted: 18 October 2007

This article is available from: http://www.biomedcentral.com/I47/-2/56/8/72

(C) 2007 Royer et al; licensee BioMed Central Ltd.

This is an Open Access article distributed under the terms of the Creative Commons Attribution License (http://creativecommons.org/licenses/by/2.0), which permits unrestricted use, distribution, and reproduction in any medium, provided the original work is properly cited.

\begin{abstract}
Background: The X-linked SRPX2 gene encodes a Sushi Repeat-containing Protein of unknown function and is mutated in two disorders of the Rolandic/Sylvian speech areas. Since it is linked to defects in the functioning and the development of brain areas for speech production, SRPX2 may thus have participated in the adaptive organization of such brain regions. To address this issue, we have examined the recent molecular evolution of the SRPX2 gene.

Results: The complete coding region was sequenced in 24 human $X$ chromosomes from worldwide populations and in six representative nonhuman primate species. One single, fixed amino acid change (R75K) has been specifically incorporated in human SRPX2 since the human-chimpanzee split. The R75K substitution occurred in the first sushi domain of SRPX2, only three amino acid residues away from a previously reported disease-causing mutation (Y72S). Three-dimensional structural modeling of the first sushi domain revealed that $Y 72$ and K75 are both situated in the hypervariable loop that is usually implicated in protein-protein interactions. The side-chain of residue 75 is exposed, and is located within an unusual and SRPX-specific protruding extension to the hypervariable loop. The analysis of nonsynonymous/synonymous substitution rate $(\mathrm{Ka} / \mathrm{Ks})$ ratio in primates was performed in order to test for positive selection during recent evolution. Using the branch models, the Ka/Ks ratio for the human branch was significantly different $(\mathrm{p}=$ 0.027 ) from that of the other branches. In contrast, the branch-site tests did not reach significance. Genetic analysis was also performed by sequencing 9,908 kilobases $(\mathrm{kb})$ of intronic SRPX2 sequences. Despite low nucleotide diversity, neither the HKA (Hudson-Kreitman-Aguadé) test nor the Tajima's D test reached significance.
\end{abstract}

Conclusion: The R75K human-specific variation occurred in an important functional loop of the first sushi domain of SRPX2, indicating that this evolutionary mutation may have functional importance; however, positive selection for R75K could not be demonstrated. Nevertheless, our data contribute to the first understanding of molecular evolution of the human SPRX2 gene. Further experiments are now required in order to evaluate the possible consequences of R75K on SRPX2 interactions and functioning. 


\section{Background}

Evolution studies have been undertaken to identify those genetic changes that underlie human-specific features such as susceptibility to acquired immunodeficiency syndrome, bipedalism, a large brain, and higher-order cognitive functions. Several phenotypic differences distinguishing human from other great apes species obviously rely on cerebral activity. Large-scale studies in human and chimpanzee using either genome comparisons $[1,2]$ or brain transcriptome analyses [3-5] have led to the identification of a subset of genes that may have contributed to the evolution of human brain anatomy and activity from a common primate ancestor. An important complementary approach has relied on the study of candidate genes selected on the basis of their importance in specific human phenotypes. Consequently, several genes involved in the structure and/or functioning of the human brain have been associated with recent positive selection: ASPM [6,7], MCPH1 [8-10], GLUD2 [11], MAOA [12,13], SHH [14], and the "speech gene" FOXP2 [15-17]. More recently, accelerated evolution of noncoding sequences has also been shown $[18,19]$.

The Rolandic and Sylvian fissures divide the cortex hemispheres of primates into their main anatomical structures. In human, these areas participate in speech production under the control of the Broca's area. We recently identified the SRPX2 gene as being responsible for two related disorders of the Rolandic and Sylvian speech areas $[20,21]$. Since it is linked to defects in the functioning and the development of such brain regions, such as epileptic seizures, oral and speech dyspraxia, or bilateral perisylvian polymicrogyria, SRPX2 may be one of the specific genes whose evolution at the DNA-level may have participated in the recent emergence of higher-order cognitive functions, including the adaptive organization of brain areas for speech production.

In this study, we have examined the molecular evolution of the SRPX2 gene. One single, fixed amino acid change occurred in the first sushi domain (also known as CCP complement control protein - module, or short consensus repeat) of SRPX2 after the human-chimpanzee split. Three-dimensional modeling showed that both this evolutionary mutation and a previously identified diseaseassociated mutation [20] lie within a hypervariable loop shared by all sushi modules and that has been implicated in some cases in protein-protein interactions [22]. Using the branch models, the synonymous/non-synonymous analysis was consistent with accelerated evolution in the human lineage but this could not be confirmed when the branch-site models were used. Population genetics tests did not reach statistical significance, indicating either that a selective sweep may have occurred more than $100000-$
200000 years ago, or that there has been no episode of positive selection on SRPX2.

\section{Results and discussion}

One single amino acid substitution (R75K) has been fixed in human SRPX2 since the human-chimpanzee split

In silico screening of publicly available databases followed by phylogenetic analysis showed that SRPX2 belongs to a family of five genes: SRPX2 itself (sushi-repeat-containing protein, X-linked 2), SRPX (sushi-repeat-containing protein, X-linked), SELP (selectin P precursor), SELE (selectin E precursor), and SVEP1 (selectin-like protein) gene (Fig. 1; Additional file 1). This family emerged during vertebrate evolution. In order to trace the recent evolutionary history of SRPX2, all coding exons were sequenced from a subset of primate species that represent key evolutionary steps: human [Genbank: NM 014467], chimpanzee [Genbank: EF369515], gorilla [Genbank: EF369516], orangutan [Genbank: EF369517], gibbon [Genbank: EF369518], macaque [Genbank: EF369519], and baboon [Genbank: EF369520]. Sequence comparison (Fig. 2)

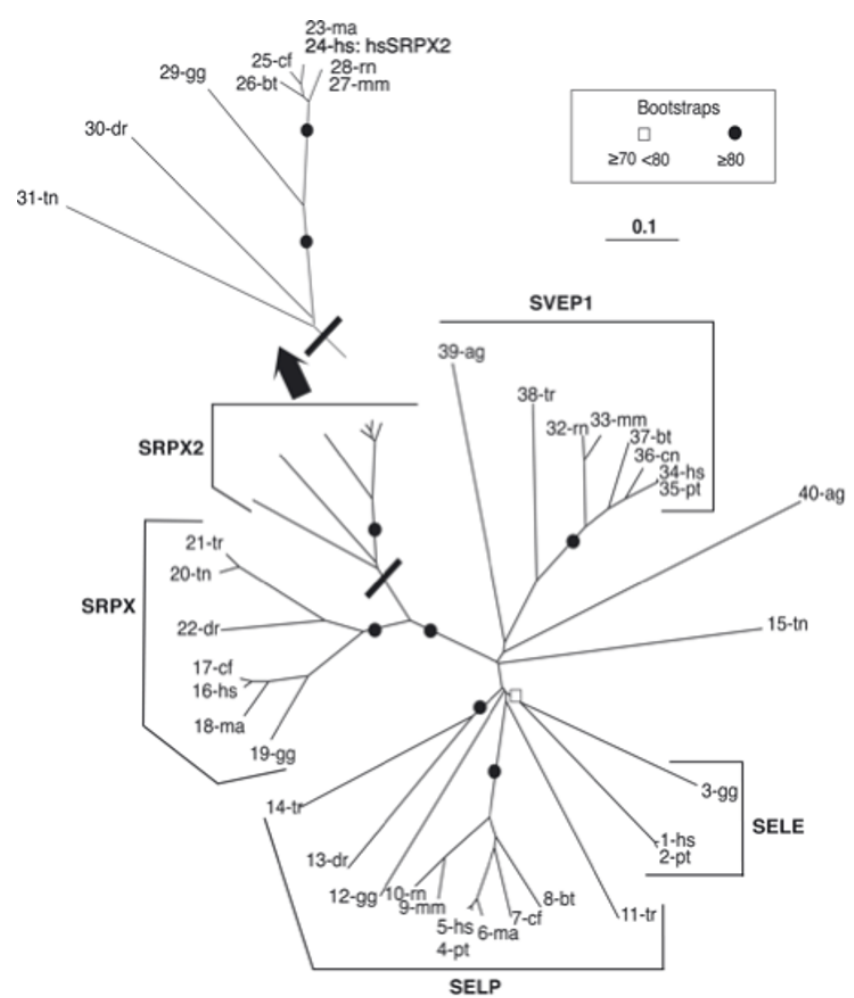

\section{Figure I}

Phylogenetic tree of the SRPX2 family members. ag: Anopheles gambiae; bt: Bos taurus; cn: Canis familiaris; dr: Danio rerio; gg: Gallus gallus; hs: Homo sapiens; mm: Mus musculus; ma: Macaca mulatta; rn: Rattus norvegicus; pt: Pan troglodytes; tn: Takifugu rubripes; tr: Tetraodon nigroviridis. The list of the ENSEMBL gene accession numbers used to construct the phylogenetic tree is available in Additional file I. 


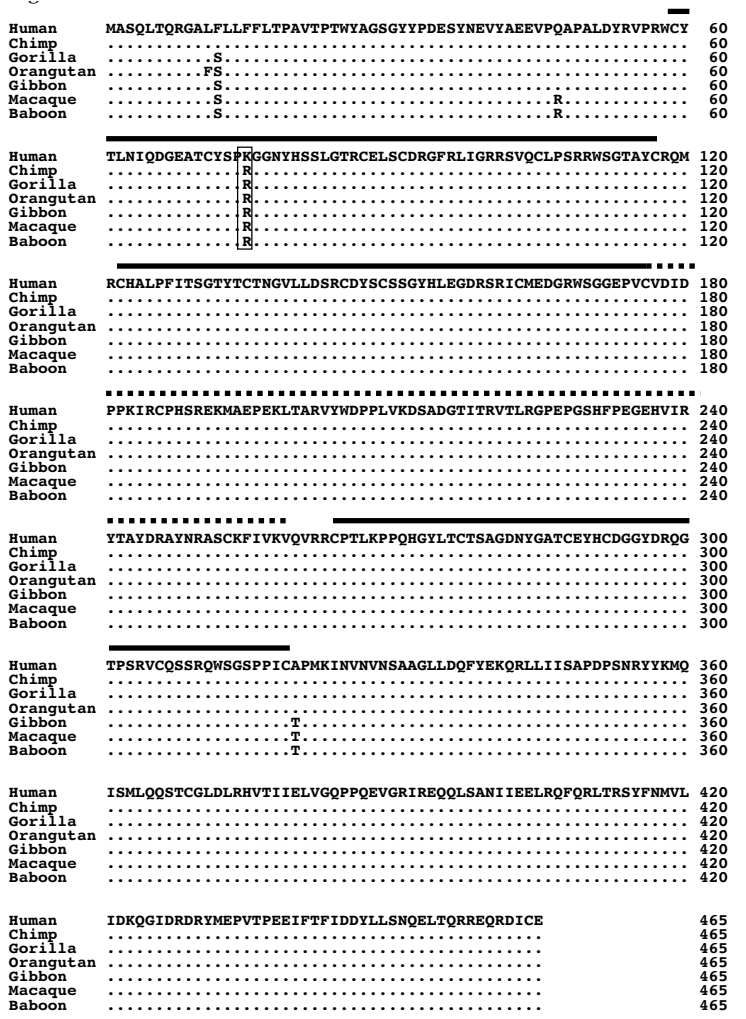

Figure 2

Amino acid sequence alignment of SRPX2 from human and nonhuman primates. Dots represent residues identical to the human amino acid sequence. Black lines represent the three Sushi domains and the dotted line represents the HYR domain. The site of the human-specific variation (R75K) is boxed.

detected only five amino acid variant sites (1.1\%; 5/465). One discrepancy between the protein [Genbank: ABN46998] predicted from the five chimpanzee SRPX2 sequences obtained here (see Methods section), and the chimpanzee SRPX2 protein [Genbank: XP 521170] predicted from the genomic sequence at the UCSC database [23], was detected (D429 in ABN46998; N429 in XP_521170). This likely corresponds to an error in the chimpanzee genome sequence previously available, although it may be due to chimpanzee polymorphism. The only amino acid substitution specific to the human lineage is an Arg to Lys change at position 75, corresponding to a $224 \mathrm{~A}>\mathrm{G}$ mutation within exon 4 of SRPX2. The possible importance of the R75K substitution in the evolution of the human species was indicated by the conservation of R75 in all SRPX2 orthologues, from nonhuman primates to ray-finned fishes, as well as by the fixation of K75 in human, as demonstrated by the lack of any variation at position 75 in silico, in the 24 worldwide X-chro- mosomes tested here, and in the 624 Caucasian control Xchromosomes previously screened [20].

\section{K75 is situated in the hypervariable loop that is usually implicated in protein-protein interactions}

The R75K human-specific modification occurred in the first sushi domain of the protein. Sushi domains have been identified in several proteins of the complement system and in the selectin family of proteins [24]. They may serve in protein-protein interactions [22], as demonstrated in the case of the neurocan-L1 interaction [25]. R75K occurs only three amino acid residues away from the tyrosine residue (Y72) that is mutated in a patient with rolandic seizures and bilateral perisylvian polymicrogyria and in his female relatives with mild mental retardation [20]. The amino acid residue at position 75 may thus participate in the proper function of the first sushi domain of SRPX2.

To further address this issue, three-dimensional modeling of the first sushi module of the human SRPX2 protein (i.e. sushi 1) was undertaken by homology with a known sushi domain (CCP module) structure (Fig. 3; Additional file 2). Sushi domains are characterised by a compact hydrophobic core, containing an almost invariant Trp residue, which is enclosed in a framework of five extended seg-

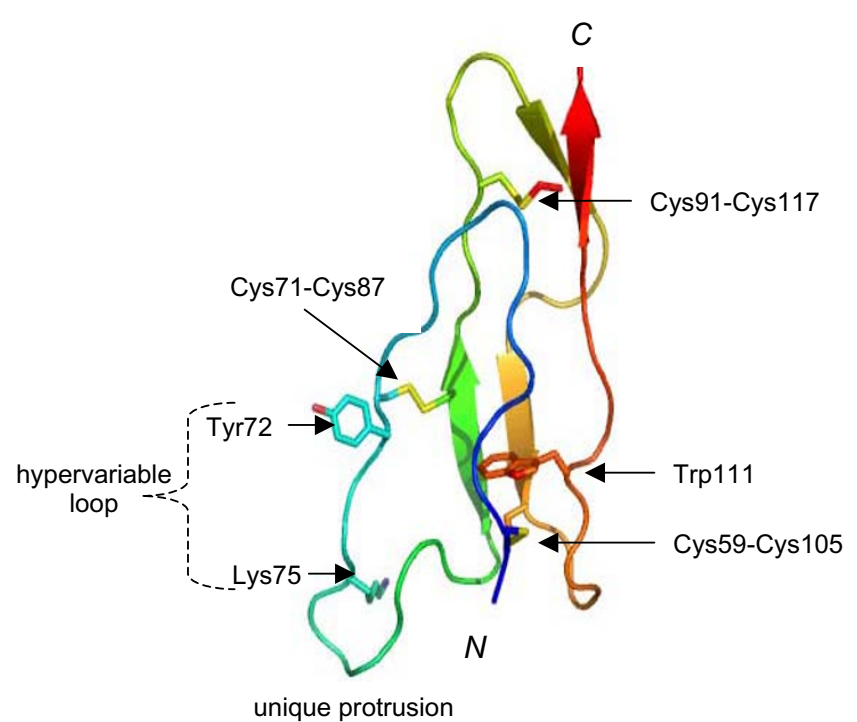

Figure 3

Three-dimensional modeling of the first sushi domain of human SRPX2. A cartoon representation [65] is shown, highlighting the conserved Trp and Cys residues. The model reveals an additional putative disulfide bridge (Cys7 I-Cys87), atypical of the classical sushi (CCP) module fold. The hypervariable loop, with the sites of disease-causing mutation (Tyr72) and evolutionary change (Lys75) and the protrusion specific to SRPX, are indicated. 
ments that form $\beta$-strands for all or part of their lengths. The extended segments are aligned with the long axis of the module and are held together by two strictly conserved disulfide bridges [24]. In a previously performed cluster assignment exercise undertaken for more than 240 sushi domain sequences [26], the first sushi domain of SRPX (which is highly similar to sushi 1) fell into cluster$\mathrm{D}$, which also includes many modules found within the selectin family of proteins.

In almost all sushi domains, a region that is highly variable in length, sequence and conformation, and commonly referred to as the hypervariable loop [27], is inserted within the second extended region. Depending on its length this projects laterally from the module and forms an obvious candidate surface for protein-protein recognition. Indeed, the hypervariable loop has been implicated as a "hot-spot" for several protein-protein interactions and disease-causing mutations in CCP-containing complement proteins [22,28-30]. In the sushi 1 model (Fig. 3) an additional disulfide bridge (cysteine residues C71-C87), atypical of the classical sushi domain fold, is evident. Cys71 lies at the beginning of the hypervariable loop that is exceptionally long in sushi 1 . The hypervariable loop is thus forced to form a prominent protrusion extending towards the N-terminus of the module. This feature has neither been seen in any experimentally determined sushi module structure to date, nor is predicted to occur in other members of the D-cluster except SRPX.

The Y72S mutation is largely solvent exposed and located within the hypervariable loop, adjacent to the cysteine residue (C71) that participates in the non-typical, third, disulfide bridge. This change from a large aromatic sidechain (tyrosine; Y) to a small, polar one (serine; S) at position 72 will have a profound effect on the surface properties of this region that is close to the aforementioned prominent protrusion. K75 is located nearby, within the protrusion, and its side-chain is exposed (Fig. 3). It is reasonable to suggest that the unique structure formed by the hypervariable loop of sushi 1 performs a role that is specific to the SRPX2 protein. Presumably, it is not a coincidence, that it is also the site of the human-specific change. An R75K substitution is a conservative one; the substitution of one exposed, positively charged residue for another can easily be accommodated by small atom shifts in surrounding side-chains, and is not likely to affect the structure of the sushi domain. Such a change might have a small but not a dramatic functional effect. Conservative substitutions are thought to play a role in adaptive change [31]. Moreover, conservative R-to-K and K-to-R substitutions can result in the altered properties of either secreted proteins [32] or the extracellular domains of some plasma membrane proteins $[33,34]$, including a member of the selectin family [35].

\section{Analysis of non-synonymous/synonymous substitution rate ratio in primates}

Human-specific modifications with putative functional consequences may sustain positive selection since the human-chimpanzee split. The ratio of non-synonymous (Ka) to synonymous (Ks) substitution rates was then calculated for each branch on the primate phylogenetic tree (Fig. 4). Using the branch models, the $\mathrm{Ka} / \mathrm{Ks}$ value in the human lineage differed from all other branches with statistical significance $(\mathrm{p}=0.027)$ (Additional file 3$)$. In this model, the calculated $\mathrm{Ka} / \mathrm{Ks}$ ratio has an infinite value, as no synonymous change has accumulated between the human and the chimpanzee. However, this elevated $\mathrm{Ka} /$ Ks ratio was not statistically $>1(\mathrm{p}=0.371)$ (Additional file 3). Using the branch-site tests, model A indicated that the K75 site might be under positive selection in the human lineage. However, model A did not differ from the null hypothesis with statistical significance $(\mathrm{p}=0.089)$ (Additional figure 3). Overall, positive selection in the human lineage could not be clearly demonstrated, as the branch-site analysis did not confirm the data obtained using the branch models. This may be due either to the actual absence of any positive selection, or to the lack of power of the tests due to the low number of genetic variations within SRPX2.

\section{Population genetics analysis}

Evidence for positive selection can also be found by analyzing the intra-specific variation in DNA sequences subjected to a selective sweep. DNA sequences adjacent to an advantageous allele should display lower-than-expected levels of diversity. The levels of polymorphism and diver-

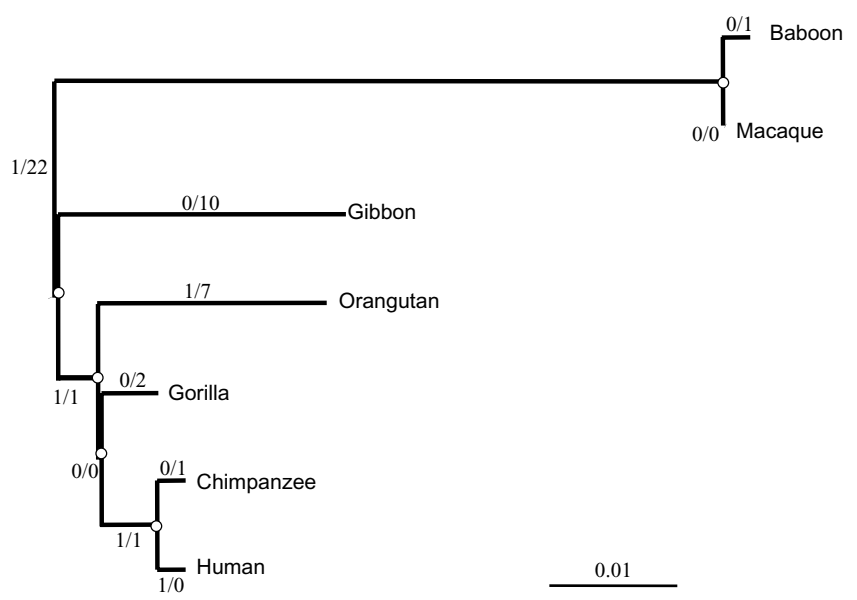

Figure 4

Numbers of non-synonymous (left) and synonymous (right) substitutions of different evolutionary lineages in primates. 
gence were estimated by sequencing a total of $9,908 \mathrm{~kb}$ of intronic sequences surrounding exon 4 of SRPX2 in the 24 $\mathrm{X}$-chromosomes mentioned above. Polymorphic sites are shown in Table 1. Nucleotide diversity at the SRPX2 locus ( $\pi=0.00036$ ) was $76 \%$ of the estimated nucleotide diversity on chromosome $X(\pi=0.00047)$ [36]. The divergence between humans and chimpanzee for SRPX2 $(D=$ $0.0075)$ was nearly identical to the average divergence calculated for X-linked intronic regions $(D=0.0072)$ [37].

The McDonald-Kreitman test [38] that measures the fraction of site under positive selection pressure by comparing the ratio of nonsynonymous to synonymous divergence and the ratio of nonsynonymous to synonymous polymorphism, was useless in the case of SRPX2 because of the very few number of inter- and intra-species DNA variations: no synonymous mutation and only one non-synonymous mutation has occurred since the humanchimpanzee split, and neither non-synonymous nor synonymous polymorphisms were detected when 24 human SRPX2 entire coding sequences from two sub-Saharan African, three Asian, three Maghrebian, and four Cauca- sian women were tested. Moreover, no polymorphism had been detected in the 198 unrelated patients previously screened for disease-causing mutations in the coding sequence of SRPX2 [20]. It is also noteworthy that while no synonymous polymorphism was found in silico, one non-synonymous variation was detected in silico [dbSNP:rs17851822]. Although the existence of a rare DNA variation cannot be ruled out, this change was detected in one single IMAGE clone only [Genbank: BC020733; IMAGE:4769946]. This is more likely to correspond to a clone artifact, as we indeed detected a large proportion of clones carrying artifactual mutations within SRPX2 inserts, using various Escherichia coli strains (unpublished data).

The HKA (Hudson-Kreitman-Aguadé) test [39] was then used in order to compare the intra- and inter-specific variations between the SRPX2 locus and control loci assumed to be under neutral selection, but did not yield significant results (Table 2). The Tajima's D test was also applied to the SRPX2 intron data. Tajima's D was clearly negative (D $=-0.646)$ but did not reach significance $(p>0.05)$. As in

Table I: Polymorphic sites of SRPX2 introns 3 and 4 in 12 women worldwide.

\begin{tabular}{|c|c|c|c|c|c|c|c|c|c|c|c|c|c|c|c|c|c|c|}
\hline \multirow[t]{2}{*}{ Site* } & \multicolumn{15}{|c|}{ Intron 3} & \multicolumn{3}{|c|}{ Intron 4} \\
\hline & 3478 & 3749 & 4292 & 4756 & 5115 & 6076 & 6783 & 7862 & 8433 & 9691 & 9700 & 10308 & 10446 & 10732 & 11286 & 2112 & 2202 & 2369 \\
\hline SNPs (ID) & $\mathrm{a}$ & $b$ & c & $d$ & e & $f$ & $g$ & $\mathrm{~h}$ & $\mathrm{i}$ & $j$ & k & I & $\mathrm{m}$ & $\mathrm{n}$ & ○ & $\mathrm{P}$ & $q$ & $r$ \\
\hline $\begin{array}{c}\text { Caucasian } \\
\text { I }\end{array}$ & $\mathrm{T} / \mathrm{T}$ & $\mathrm{C} / \mathrm{C}$ & $\mathrm{C} / \mathrm{C}$ & $\mathrm{C} / \mathrm{C}$ & $\mathrm{C} / \mathrm{C}$ & $\mathrm{C} / \mathrm{C}$ & $\mathrm{G} / \mathrm{G}$ & $\mathrm{A} / \mathrm{A}$ & $\mathrm{G} / \mathrm{G}$ & $\mathrm{A} / \mathrm{A}$ & $\mathrm{T} / \mathrm{T}$ & $\mathrm{T} / \mathrm{T}$ & $T / T$ & $\mathrm{C} / \mathrm{C}$ & $\mathrm{G} / \mathrm{G}$ & $\mathrm{T} / \mathrm{T}$ & $\mathrm{C} / \mathrm{C}$ & $\mathrm{A} / \mathrm{A}$ \\
\hline $\begin{array}{c}\text { Caucasian } \\
2\end{array}$ & $\mathrm{~T} / \mathrm{T}$ & $\mathrm{C} / \mathrm{C}$ & $\mathrm{C} / \mathrm{C}$ & $\mathrm{C} / \mathrm{T}$ & $\mathrm{C} / \mathrm{C}$ & $\mathrm{C} / \mathrm{C}$ & G/G & $\mathrm{A} / \mathrm{A}$ & G/G & $\mathrm{A} / \mathrm{A}$ & $\mathrm{T} / \mathrm{T}$ & T/A & $\mathrm{T} / \mathrm{T}$ & $\mathrm{C} / \mathrm{C}$ & $\mathrm{G} / \mathrm{G}$ & $\mathrm{T} / \mathrm{T}$ & $\mathrm{C} / \mathrm{C}$ & $\mathrm{A} / \mathrm{A}$ \\
\hline $\begin{array}{c}\text { Caucasian } \\
3\end{array}$ & $\mathrm{~T} / \mathrm{T}$ & $\mathrm{C} / \mathrm{C}$ & $\mathrm{C} / \mathrm{C}$ & $\mathrm{C} / \mathrm{C}$ & $\mathrm{C} / \mathrm{C}$ & $\mathrm{C} / \mathrm{C}$ & G/G & $\mathrm{A} / \mathrm{C}$ & G/G & $\mathrm{A} / \mathrm{G}$ & $\mathrm{T} / \mathrm{C}$ & $\mathrm{T} / \mathrm{T}$ & $T / T$ & $\mathrm{C} / \mathrm{T}$ & $\mathrm{G} / \mathrm{G}$ & $\mathrm{T} / \mathrm{T}$ & $\mathrm{C} / \mathrm{C}$ & $\mathrm{A} / \mathrm{A}$ \\
\hline $\begin{array}{c}\text { Caucasian } \\
4\end{array}$ & $\mathrm{~T} / \mathrm{T}$ & $\mathrm{C} / \mathrm{C}$ & $\mathrm{C} / \mathrm{C}$ & $\mathrm{C} / \mathrm{C}$ & $\mathrm{C} / \mathrm{C}$ & $\mathrm{C} / \mathrm{C}$ & G/G & $\mathrm{A} / \mathrm{A}$ & G/G & $\mathrm{A} / \mathrm{A}$ & $\mathrm{T} / \mathrm{T}$ & $\mathrm{T} / \mathrm{T}$ & $\mathrm{T} / \mathrm{T}$ & $\mathrm{C} / \mathrm{C}$ & $\mathrm{G} / \mathrm{G}$ & $\mathrm{T} / \mathrm{T}$ & $\mathrm{C} / \mathrm{C}$ & $\mathrm{A} / \mathrm{A}$ \\
\hline$\underset{\text { I }}{\text { Maghrebia }}$ & $\mathrm{T} / \mathrm{T}$ & $\mathrm{C} / \mathrm{C}$ & $\mathrm{C} / \mathrm{C}$ & $\mathrm{C} / \mathrm{C}$ & $\mathrm{C} / \mathrm{C}$ & $\mathrm{C} / \mathrm{C}$ & $\mathrm{G} / \mathrm{G}$ & $\mathrm{A} / \mathrm{A}$ & $\mathrm{G} / \mathrm{G}$ & $\mathrm{A} / \mathrm{A}$ & $\mathrm{T} / \mathrm{T}$ & $\mathrm{T} / \mathrm{T}$ & $\mathrm{T} / \mathrm{T}$ & $\mathrm{C} / \mathrm{C}$ & $\mathrm{G} / \mathrm{G}$ & $\mathrm{T} / \mathrm{T}$ & $\mathrm{C} / \mathrm{C}$ & $\mathrm{A} / \mathrm{A}$ \\
\hline $\begin{array}{c}\text { Maghrebia } \\
2\end{array}$ & $\mathrm{~T} / \mathrm{G}$ & $\mathrm{C} / \mathrm{C}$ & $\mathrm{C} / \mathrm{C}$ & $\mathrm{C} / \mathrm{C}$ & $\mathrm{C} / \mathrm{C}$ & $\mathrm{C} / \mathrm{C}$ & $\mathrm{G} / \mathrm{G}$ & $\mathrm{A} / \mathrm{C}$ & $\mathrm{G} / \mathrm{G}$ & $\mathrm{A} / \mathrm{G}$ & $\mathrm{T} / \mathrm{C}$ & $\mathrm{T} / \mathrm{T}$ & $T / T$ & $\mathrm{C} / \mathrm{C}$ & $\mathrm{G} / \mathrm{G}$ & $\mathrm{T} / \mathrm{T}$ & $\mathrm{C} / \mathrm{C}$ & $\mathrm{A} / \mathrm{A}$ \\
\hline $\begin{array}{c}\text { Maghrebia } \\
3\end{array}$ & $\mathrm{~T} / \mathrm{T}$ & $\mathrm{C} / \mathrm{C}$ & $\mathrm{C} / \mathrm{C}$ & $\mathrm{C} / \mathrm{C}$ & $\mathrm{C} / \mathrm{C}$ & $\mathrm{C} / \mathrm{C}$ & $\mathrm{G} / \mathrm{G}$ & $\mathrm{A} / \mathrm{A}$ & $\mathrm{G} / \mathrm{G}$ & $\mathrm{A} / \mathrm{A}$ & $\mathrm{T} / \mathrm{T}$ & $\mathrm{T} / \mathrm{T}$ & $T / T$ & $\mathrm{C} / \mathrm{C}$ & $\mathrm{G} / \mathrm{G}$ & $\mathrm{T} / \mathrm{T}$ & $\mathrm{C} / \mathrm{C}$ & $\mathrm{A} / \mathrm{A}$ \\
\hline $\begin{array}{c}\text { Asian } \\
\text { I }\end{array}$ & $\mathrm{T} / \mathrm{T}$ & $\mathrm{C} / \mathrm{C}$ & $\mathrm{C} / \mathrm{C}$ & $\mathrm{C} / \mathrm{C}$ & $\mathrm{C} / \mathrm{C}$ & $\mathrm{C} / \mathrm{C}$ & G/G & $\mathrm{A} / \mathrm{C}$ & $\mathrm{G} / \mathrm{A}$ & $\mathrm{A} / \mathrm{G}$ & $\mathrm{T} / \mathrm{C}$ & $\mathrm{T} / \mathrm{T}$ & $\mathrm{T} / \mathrm{T}$ & $\mathrm{C} / \mathrm{T}$ & $\mathrm{G} / \mathrm{G}$ & $\mathrm{C} / \mathrm{C}$ & $\mathrm{C} / \mathrm{C}$ & $\mathrm{A} / \mathrm{A}$ \\
\hline $\begin{array}{c}\text { Asian } \\
2\end{array}$ & $\mathrm{~T} / \mathrm{T}$ & $\mathrm{C} / \mathrm{C}$ & $\mathrm{C} / \mathrm{C}$ & $\mathrm{C} / \mathrm{C}$ & $\mathrm{C} / \mathrm{C}$ & $\mathrm{C} / \mathrm{C}$ & $\mathrm{G} / \mathrm{G}$ & $\mathrm{A} / \mathrm{A}$ & $\mathrm{G} / \mathrm{G}$ & $\mathrm{A} / \mathrm{A}$ & $\mathrm{T} / \mathrm{T}$ & $\mathrm{T} / \mathrm{T}$ & $T / T$ & $\mathrm{C} / \mathrm{C}$ & $\mathrm{G} / \mathrm{G}$ & $\mathrm{T} / \mathrm{T}$ & $\mathrm{C} / \mathrm{C}$ & $\mathrm{A} / \mathrm{A}$ \\
\hline $\begin{array}{c}\text { Asian } \\
3\end{array}$ & $\mathrm{~T} / \mathrm{T}$ & $\mathrm{C} / \mathrm{C}$ & $\mathrm{C} / \mathrm{C}$ & $\mathrm{C} / \mathrm{C}$ & $\mathrm{C} / \mathrm{C}$ & $\mathrm{C} / \mathrm{C}$ & $\mathrm{G} / \mathrm{G}$ & $\mathrm{A} / \mathrm{C}$ & $\mathrm{G} / \mathrm{A}$ & $\mathrm{A} / \mathrm{G}$ & $\mathrm{T} / \mathrm{C}$ & $\mathrm{T} / \mathrm{T}$ & $T / T$ & $\mathrm{C} / \mathrm{T}$ & $\mathrm{G} / \mathrm{G}$ & $\mathrm{T} / \mathrm{C}$ & $\mathrm{C} / \mathrm{C}$ & $\mathrm{A} / \mathrm{A}$ \\
\hline $\begin{array}{c}\text { African } \\
\text { I }\end{array}$ & $\mathrm{G} / \mathrm{G}$ & $\mathrm{C} / \mathrm{C}$ & $\mathrm{C} / \mathrm{C}$ & $\mathrm{C} / \mathrm{C}$ & $\mathrm{C} / \mathrm{C}$ & $\mathrm{C} / \mathrm{T}$ & $\mathrm{G} / \mathrm{G}$ & $\mathrm{C} / \mathrm{C}$ & $\mathrm{G} / \mathrm{G}$ & $\mathrm{G} / \mathrm{G}$ & $\mathrm{C} / \mathrm{C}$ & $\mathrm{T} / \mathrm{T}$ & $T / T$ & $\mathrm{C} / \mathrm{T}$ & $\mathrm{T} / \mathrm{G}$ & $\mathrm{T} / \mathrm{T}$ & $\mathrm{C} / \mathrm{T}$ & $\mathrm{A} / \mathrm{G}$ \\
\hline $\begin{array}{c}\text { African } \\
2\end{array}$ & $\mathrm{G} / \mathrm{G}$ & $\mathrm{T} / \mathrm{T}$ & $\mathrm{G} / \mathrm{G}$ & $\mathrm{C} / \mathrm{C}$ & $\mathrm{T} / \mathrm{T}$ & $\mathrm{C} / \mathrm{C}$ & $\mathrm{A} / \mathrm{A}$ & $\mathrm{C} / \mathrm{C}$ & G/G & $\mathrm{G} / \mathrm{G}$ & $\mathrm{C} / \mathrm{C}$ & $\mathrm{T} / \mathrm{T}$ & $\mathrm{C} / \mathrm{C}$ & $T / T$ & $\mathrm{G} / \mathrm{G}$ & $\mathrm{T} / \mathrm{T}$ & $\mathrm{C} / \mathrm{C}$ & $\mathrm{G} / \mathrm{G}$ \\
\hline
\end{tabular}

\footnotetext{
* Numbers refer to the positions in the sequences of human introns 3 and 4, respectively. ** For those single nucleotide polymorphisms (SNPs) that were not reported in current databases $[23,66]$ at the time of analysis and that appeared in one single individual only, PCRs were redone and both strands resequenced in order to exclude PCR artifacts. SNPs IDs at NCBI [66] are: a: rs66I6I7I. b: ss5204855 I. c: ss52048547. d: ss52085994. e: ss52048549. f: ss52084549. g: ss52084548. h: rs59667I I. i: ss52048552. j: ss52048553. k: ss52048554. l: ss52048546. m: rs592।619. n: rs5920840. o: ss52084547. p: rs5921620. q: ss52048548. r: rs2022475.
} 
Table 2: Nucleotide polymorphism and divergence at SRPX2

\begin{tabular}{ccccccc}
\hline & Sequence length $(\mathrm{nt})$ & $\pi(\%)$ & $\theta(\%)$ & Divergence $D(\%)$ & $\theta / D$ & HKA probability \\
\hline B-globin initiation at IIpI5 [67] & 6076 & 0.129 & 0.107 & 1.284 & 0.083 & 0.696 \\
Noncoding region at 22qII [68] & 9901 & 0.088 & 0.139 & 1.353 & 0.103 & 0.605 \\
Dystrophin intron-dys44 at Xp2I [69] & 7475 & 0.135 & 0.102 & 0.604 & 0.169 & 0.499 \\
PDHAI introns at Xp22 [70] & 3530 & 0.225 & 0.211 & 0.992 & 0.213 & 0.168 \\
Noncoding region at Xq13.3 [7I] & 10200 & 0.045 & 0.083 & 0.922 & 0.090 & 0.655 \\
SRPX2 introns at Xq22 (this study) & 9908 & $0.048(0.036)$ & $0.062(0.047)$ & 0.750 & 0.084 & \\
\hline
\end{tabular}

nt: nucleotide; $\pi$ : nucleotide diversity per site; for $X$ chromosome data, $\pi$ is corrected by multiplication by $4 / 3$ and the uncorrected value is in brackets. $\theta$ : Watterson's estimate of polymorphism per site; for $\mathrm{X}$ chromosome data, $\theta$ is corrected by multiplication by $4 / 3$ and the uncorrected value is in brackets. D: number of nucleotide differences per site between human and chimpanzee sequences. HKA probability: probability from the HKA test, with comparison to the SRPX2 intron data.

the case of the ASPM gene that is involved in human brain expansion [6], the present intra-specific analyses did not show significant evidence against neutral expectations. The lack of statistical significance may indicate that no selective sweep has ever occurred in the human lineage. However, it should be mentioned that a selective sweep can be detected by intra-specific studies only for a short period $(<0.5 \mathrm{~N}$ generations, where $N$ is the effective human population size, i.e. approximately $<100000-$ 200000 years ago) after fixation of the advantageous variant $[40,41]$.

\section{Conclusion}

In this study, we have examined the molecular evolution of the SRPX2 gene that causes brain disorders of the speech areas. One single, fixed amino acid change (R75K) occurred in the first sushi domain of SRPX2 after the human-chimpanzee split. Neither the primate analysis nor the population genetics separately demonstrated the existence of positive selection of SRPX2. Whether the single human-specific R75K mutation has sustained positive selection thus remains an open question. However the 3D location of R75K right within an important functional domain of the SRPX2 protein, in the immediate vicinity of a pathogenic mutation, indicates that this evolutionary mutation may have functional importance. Because R75K occurred in a domain implicated in protein-protein interactions, it is possible that qualitative or quantitative changes in the interaction with one or several putative SRPX2 partners have been modified. Despite the present lack of any knowledge on either the actual function of SRPX2 or the proteins it interacts with, it is obvious that the comparison of the properties of the human and chimpanzee SRPX2 orthologues will help determine in the future if and how new functions were acquired. From this viewpoint, our study represents a first important step towards the analysis of the consequences of $\mathrm{R} 75 \mathrm{~K}$ on SRPX2 functioning and protein interactions.

\section{Methods DNA samples and sequencing}

All human and nonhuman primate DNAs were extracted using standard procedures and according to the appropriate ethical committees and animal' care rules, respectively. Polymerase chain reaction (PCR) fragments representing $9,908 \mathrm{~kb}$ from introns 3 and 4 were sequenced with specific primers in 12 human females from the major continental populations (two sub-Saharan Africans, four Europeans, three Asians, and three Maghrebians). Each exon of the full-length coding region of SRPX2 was amplified by PCR and sequenced in the same 12 women and in six nonhuman primate species, using inter-specific consensus intronic primers. The nonhuman primates were of the hominidae, pongidae, hylobatidae, and cercopithecidae families: three chimpanzees (one male and two females; Pan troglodytes); one gorilla (Gorilla gorilla); one orangutan (Pongo pygmaeus), one gibbon (Hylobates sp.), one macaque (Macaca mulatta) and one baboon (Papio sp.). The primer sequences are listed in Additional file 4. Sequencing was performed using standard dye terminator chemistry. Sequences were analysed and polymorphisms detected using the Genalys 3.0 software [42]. Multiple sequence alignments were performed using the ClustalW program [43].

\section{Modeling analyses}

Modeling of the first sushi module of human SRPX2 was undertaken based upon its closest homologue in the Protein Data Bank (PDB) $[44,45]$ : the highest resolved X-ray structure of the first sushi module of complement receptor type 2 (PDB ID: 1LY2) [46], which was identified with a BLAST search $[47,48]$. The target and template shared $29 \%$ sequence identity from N- to C-terminal cysteines. The program Modeller release 8 version 1 [49] was used.

The alignment between the target and template sequences was based on an initial multiple sequence alignment of several individual human sushi-module sequences assigned to cluster-D (with the addition of template sequence CR2 module 1), using the program ProbCons 
[50] to help position indels more appropriately (see Additional file 2 for target-template alignment). Cluster-D members, according to the recently published convention of sequence assignment [26], are characterized by the presence of a six-cysteine residue motif, forming three putative disulfide bridges. The target-template sequence alignment was subjected to further, minor manual editing guided by positioning of secondary structure elements more appropriately between the target and template sequences; secondary structure was predicted by the server PsiPred version $2.4[51,52]$ for the target sequence, or identified by DSSP [53] for the template structure. The additional putative disulfide bridge present in the target (absent in its corresponding template) was restrained during model building. Twenty-five models were generated, and the one with the lowest objective function score [49] selected as the representative model. The loop KGGNY in the hypervariable loop region of SRPX2, for which CR2template-derived restraints were largely absent was subsequently remodeled under SYBYL version 6.9 (Tripos Associates, St. Louis, MO, USA) after we conducted a loop search for that region against a high resolution subset of the PDB, in order to select the best root-mean square fitting matching loop conformation for that region.

Non-identical side-chain residues of the representative model were optimized using the side-chain replacement program SCWRL version 3 [54]. The model was then protonated and subjected to energy minimization using the Tripos forcefield [55] (20 steps steepest descent followed by 20 steps conjugate gradient) under SYBYL to remove clashes and bad geometries. The model structure was finally checked for valid stereochemistry using PROCHECK version 3.5.4 [56].

\section{Evolution data analyses}

The phylogenetic analysis was performed using the phylogenomic analysis pipeline available in the FIGENIX [57] automated genomic annotation platform [58] with the human SRPX2 protein sequence [Genbank: NP 055282] as input and the NCBI nr or the Ensembl databases for BLAST searches (Additional file 1). The synonymous/non synonymous analyses were conducted in primates assuming the following unrooted tree topology: (Baboon, Macaque, ((((Chimpanzee, Human), Gorilla), Orangu$\tan )$, Gibbon)). Ancestral sequences were reconstructed with the pamp and codeml programs in the PAML package $[59,60]$, using the parsimony method and the maximum likelihood method, respectively. From these data, the number of synonymous and non-synonymous substitutions and the $\mathrm{Ka} / \mathrm{Ks}$ ratios were estimated using the DnaSP 4.0 package [61]. The codeml program from the PAML 3.15 packages was used to test for positive selection, using the branch models and the branch-site models, as previously described [62,63] (Additional file 3).
The DnaSP 4.0 program was also used for all population genetic analyses. Nucleotide diversity $(\pi)$ and Watterson's $\theta$ were computed as described [64]. The neutral evolution hypothesis for the SRPX2 intronic polymorphisms was checked with the HKA (Hudson-Kreitman-Aguadé) test [39], using available data on worldwide polymorphisms in non-coding reference (neutral) autosomal and X-linked regions of the human genome (Table 2), as previously described [16].

\section{Competing interests}

The author(s) declares that there are no competing interests.

\section{Authors' contributions}

BR carried out the evolutionary genetics studies in nonhuman primates and in human; performed the statistical analyses; participated in the conception and the design of the study and in the drafting of the manuscript. DCS and PNB carried out the 3-D modeling analysis and participated in the drafting of the manuscript. REB and $A B$ participated in the genetic study of nonhuman primates. PR and ARS participated in the sequence alignments and analyses. AL participated in the statistical analyses. PC participated in the design of the study and in the drafting of the manuscript. PP participated in the design of the study, in the phylogenetic analysis and in the drafting of the manuscript. PS conceived of the study and participated in its design and coordination and in the drafting of the manuscript. All authors read and approved the final manuscript.

\section{Additional material}

\section{Additional file 1}

List of the ENSEMBL gene accession numbers. The sequences corresponding to the gene accession numbers were used to construct the phylogenetic tree depicted in Fig. 1.

Click here for file

[http://www.biomedcentral.com/content/supplementary/14712156-8-72-S1.doc]

\section{Additional file 2}

Target-template alignment used for modelling. This figure represents the output file for optimal sequence alignment between target sushi 1 of SRPX2 and template CR2 sushi module 1.

Click here for file

[http://www.biomedcentral.com/content/supplementary/14712156-8-72-S2.doc]

\section{Additional file 3}

Analysis of positive selection along the human lineage. The data represent the statistical analysis that was used to test for positive selection, using the branch models and the branch-site models.

Click here for file

[http://www.biomedcentral.com/content/supplementary/1471-

2156-8-72-S3.doc] 


\section{Additional file 4}

List of PCR primers. The 'Exons' PCR primers were used to amplify exons of the full-length coding region of SRPX2 in 12 human females and in six nonhuman primate species. The 'Introns' PCR primers were used to amplify human genomic fragments from introns 3 and 4 of SRPX2 in the same 12 women.

Click here for file

[http://www.biomedcentral.com/content/supplementary/14712156-8-72-S4.doc]

\section{Acknowledgements}

We thank all the control individuals who participated in this study. Each participant gave informed consent prior to the study, according to the appropriate local ethical committee. We thank Ziheng Yang for his help with the use of the codeml program from the PAML package, Nicolas Galtier for helpful discussion and comments and for critical reading of the manuscript, Donna Devine for help in editing the manuscript, and Gaby Doxiadis for the sending of nonhuman primate DNAs. Assistance from the "Genome Variation" core facilities (Marseille-Nice Génopôle) and from the Marseille Biological Resource Centre (BRC) was greatly appreciated. This study was supported by INSERM. BR is a recipient of a French MRT (Ministry of Research and Technology) PhD fellowship and PR has been a recipient of a LFCE (Ligue Française Contre l'Epilepsie) fellowship.

\section{References}

I. Clark AG, Glanowski S, Nielsen R, Thomas PD, Kejariwal A, Todd MA, Tanenbaum DM, Civello D, Lu F, Murphy B, Ferriera S, Wang G, Zheng X, White TJ, Sninsky JJ, Adams MD, Cargill M: Inferring nonneutral evolution from human-chimp-mouse orthologous gene trios. Science 2003, 302:1960-1963.

2. Nielsen R, Bustamante C, Clark AG, Glanowski S, Sackton TB, Hubisz MJ, Fledel-Alon A, Tanenbaum DM, Civello D, White TJ, J Sninsky J, Adams MD, Cargill M: A scan for positively selected genes in the genomes of humans and chimpanzees. PLoS Biol 2005, 3:e I70.

3. Enard W, Khaitovich P, Klose J, Zollner S, Heissig F, Giavalisco P, Nieselt-Struwe K, Muchmore E, Varki A, Ravid R, Doxiadis GM, Bontrop RE, Paabo S: Intra- and interspecific variation in primate gene expression patterns. Science 2002, 296:340-343.

4. Caceres M, Lachuer J, Zapala MA, Redmond JC, Kudo L, Geschwind $\mathrm{DH}$, Lockhart DJ, Preuss TM, Barlow C: Elevated gene expression levels distinguish human from non-human primate brains. Proc Natl Acad Sci USA 2003, 100: I 3030-1 3035.

5. Khaitovich P, Muetzel B, She X, Lachmann M, Hellmann I, Dietzsch J, Steigele S, Do HH, Weiss G, Enard W, Heissig F, Arendt T, NieseltStruwe K, Eichler EE, Paabo S: Regional patterns of gene expression in human and chimpanzee brains. Genome Res 2004, | 4: | 462-| 473 .

6. Zhang J: Evolution of the human ASPM gene, a major determinant of brain size. Genetics 2003, 165:2063-2070.

7. Mekel-Bobrov N, Gilbert SL, Evans PD, Vallender EJ, Anderson JR, Hudson RR, Tishkoff SA, Lahn BT: Ongoing adaptive evolution of ASPM, a brain size determinant in Homo sapiens. Science 2005, 309: 1720-1722

8. Evans PD, Anderson JR, Vallender EJ, Choi SS, Lahn BT: Reconstructing the evolutionary history of microcephalin, a gene controlling human brain size. Hum Mol Genet 2004, 13:1139-I I45.

9. Wang YQ, Su B: Molecular evolution of microcephalin, a gene determining human brain size. Hum Mol Genet 2004, |3:1|3|-|137

10. Evans PD, Gilbert SL, Mekel-Bobrov N, Vallender EJ, Anderson JR, Vaez-Azizi LM, Tishkoff SA, Hudson RR, Lahn BT: Microcephalin, a gene regulating brain size, continues to evolve adaptively in humans. Science 2005, 309:1717-1720.

II. Burki F, Kaessmann H: Birth and adaptive evolution of a hominoid gene that supports high neurotransmitter flux. Nat Genet 2004, 36:106I-1063.
12. Gilad Y, Rosenberg S, Przeworski M, Lancet D, Skorecki K: Evidence for positive selection and population structure at the human MAO-A gene. Proc Natl Acad Sci USA 2002, 99:862-867.

13. Andres AM, Soldevila M, Navarro A, Kidd KK, Oliva B, Bertranpetit ]: Positive selection in MAOA gene is human exclusive: determination of the putative amino acid change selected in the human lineage. Hum Genet 2004, I I 5:377-386.

14. Dorus S, Anderson JR, Vallender EJ, Gilbert SL, Zhang L, Chemnick LG, Ryder OA, Li W, Lahn BT: Sonic Hedgehog, a key development gene, experienced intensified molecular evolution in primates. Hum Mol Genet 2006, 15:203I-2037.

15. Enard W, Przeworski M, Fisher SF, Lai CS, Wiebe V, Kitano T, Monaco AP, Paabo S: Molecular evolution of FOXP2, a gene involved in speech and language. Nature 2002, 41 8:869-872.

16. Zhang J, Webb DM, Podlaha O: Accelerated protein evolution and origins of human-specific features: Foxp2 as an example. Genetics 2002, 162:1825-1835.

17. Fisher SE, Marcus GF: The eloquent ape: genes, brains and the evolution of language. Nat Rev Genet 2006, 7:9-20.

18. Prabhakar S, Noonan JP, Paabo S, Rubin EM: Accelerated evolution of conserved noncoding sequences in humans. Science 2006, 3I 4:786.

19. Pollard KS, Salama SR, Lambert N, Lambot MA, Coppens S, Pedersen JS, Katzman S, King B, Onodera C, Siepel A, Kern AD, Dehay C, Igel $H$, Ares $M J r$, Vanderhaeghen $P$, Haussler D: An RNA gene expressed during cortical development evolved rapidly in humans. Nature 2006, 443: 167-172.

20. Roll P, Rudolf G, Pereira S, Royer B, Scheffer IE, Massacrier A, Valenti MP, Roeckel-Trevisiol N, Jamali S, Beclin C, Seegmuller C, Metz-Lutz MN, Lemainque A, Delepine M, Caloustian C, de Saint Martin A, Bruneau N, Depetris D, Mattei MG, Flori E, Robaglia-Schlupp A, Levy N, Neubauer BA, Ravid R, Marescaux C, Berkovic SF, Hirsch E, Lathrop M, Cau P, Szepetowski P: SRPX2 mutations in disorders of language cortex and cognition. Hum Mol Genet 2006, 15:1195-1207.

21. The Online Mendelian Inheritance in Man database [http:// www.ncbi.nlm.nih.gov/entrez/query.fcgi?db=OMIM]

22. Jenkins HT, Mark L, Ball G, Persson J, Lindahl G, Uhrin D, Blom AM, Barlow PN: Human C4b-binding protein - structural basis for interaction with streptococcal $M$ protein, a major bacterial virulence factor. J Biol Chem 2006, $281: 3690-3697$.

23. The Genome Browser Database [http://genome.ucsc.edu/cgibin/hgGateway]

24. Kirkitadze MD, Barlow PN: Structure and flexibility of the multiple domain proteins that regulate complement activation. Immunol Rev 200I, I80:146-16I.

25. Oleszewski M, Gutwein $P$, von der Lieth $W$, Rauch U, Altevogt $P$ : Characterization of the LI-neurocan-binding site Implications for LI-LI homophilic binding. J Biol Chem 2000, 275:34478-34485.

26. Soares DC, Gerloff DL, Syme NR, Coulson AF, Parkinson J, Barlow PN: Large-scale modelling as a route to multiple surface comparisons of the CCP module family. Protein Eng Des Sel 2005, 18:379-388.

27. Soares DC, Barlow PN: Structural Biology of the Complement System Edited by: Morikis D, Lambris JD. Boca Raton: CRC Press, Taylor \& Francis Group; 2005: 19-62.

28. Richards A, Kemp EJ, Liszewski MK, Goodship JA, Lampe AK, Decorte R, Muslumanoglu MH, Kavukcu S, Filler G, Pirson Y, Wen LS, Atkinson JP, Goodship TH: Mutations in human complement regulator, membrane cofactor protein (CD46), predispose to development of familial hemolytic uremic syndrome. Proc Natl Acad Sci 2003, 100: I2966-1297I.

29. Herbert AP, Uhrin D, Lyon M, Pangburn MK, Barlow PN: Diseaseassociated sequence variations congregate in a polyanionrecognition patch on human factor $H$ revealed in 3D structure. I Biol Chem 2006, 28 I: 165 I2-16520.

30. Herbert A, Soares DC, Pangburn MK, Barlow PN: Disease-associated sequence variants in factor $\mathrm{H}$ : a structural biology approach. Adv Exp Med Biol 2006, 586:3 I3-327.

31. Wyckoff GJ, Wang W, Wu Cl: Rapid evolution of male reproductive genes in the descent of man. Nature 2000, 403:304-309.

32. Higuchi M, Kazazian HH Jr, Kasch L, Warren TC, McGinniss MJ, Phillips JA 3rd, Kasper C, Janco R, Antonarakis SE: Molecular characterization of severe hemophilia $A$ suggests that about half the mutations are not within the coding regions and splice 
junctions of the factor VIII gene. Proc Natl Acad Sci USA 199I, 88:7405-7409.

33. Vinson M, van der Merwe PA, Kelm S, May A, Jones EY, Crocker PR: Characterization of the sialic acid-binding site in sialoadhesin by site-directed mutagenesis. J Biol Chem 1996, 27 I:9267-9272.

34. Rodien P, Bremont C, Sanson ML, Parma J, Van Sande J, Costagliola S, Luton JP, Vassart G, Duprez L: Familial gestational hyperthyroidism caused by a mutant thyrotropin receptor hypersensitive to human chorionic gonadotropin. N Engl J Med 1998, 339: $1823-1826$

35. Erbe DV, Wolitzky BA, Presta LG, Norton CR, Ramos RJ, Burns DK, Rumberger JM, Rao BN, Foxall C, Brandley BK, Lasky LA: Identification of an E-selectin region critical for carbohydrate recognition and cell adhesion. J Cell Biol 1992, I I 9:2 I5-227.

36. The international SNP map working group: A map of human genome sequence variation containing $\mathbf{1 . 4 2}$ million single nucleotide polymorphisms. Nature 200I, 409:928-933.

37. Nachman MW, Bauer VL, Crowell SL, Aquadro CF: DNA variability and recombination rates at $\mathbf{X}$-linked loci in humans. Genetics 1998, 150:1|33-||4|.

38. McDonald JH, Kreitman M: Adaptive protein evolution at the Adh locus in Drosophila. Nature 1991, 35 I:652-654.

39. Hudson RR, Kreitman M, Aguade M: A test of neutral molecular evolution based on nucleotide data. Genetics 1987, I 16:153-159.

40. Simonsen KL, Churchill GA, Aquadro CF: Properties of statistical tests of neutrality for DNA polymorphism data. Genetics 1995, I 41:4 | 3-429.

4I. Enard W, Paabo S: Comparative primate genomics. Annu Rev Genomics Hum Genet 2004, 5:35I-378.

42. Takahashi M, Matsuda F, Margetic N, Lathrop M: Automated identification of single nucleotide polymorphisms from sequencing data. J Bioinform Comput Biol 2003, I:253-265.

43. The European Bioinformatics Institute [http://www.ebi.ac.uk/ clustalw/]

44. The Protein Data Bank [http://www.rcsb.org/pdb]

45. Berman HM, Westbrook J, Feng Z, Gilliland G, Bhat TN, Weissig H, Shindyalov IN, Bourne PE: The Protein Data Bank. Nucleic Acids Res 2000, 28:235-242

46. Prota $A E$, Sage $D R$, Stehle $T$, Fingeroth JD: The crystal structure of human CD2 I: Implications for Epstein-Barr virus and C3d binding. Proc Natl Acad Sci USA 2002, 99: I 064I - 10646.

47. Altschul SF, Gish W, Miller W, Myers EW, Lipman DJ: Basic local alignment search tool. J Mol Biol 1990, 215:403-4I0.

48. Altschul SF, Madden TL, Schaffer AA, Zhang J, Zhang Z, Miller W, Lipman DJ: Gapped BLAST and PSI-BLAST: a new generation of protein database search programs. Nucleic Acids Res 1997, 25:3389-3402.

49. Sali A, Blundell TL: Comparative protein modelling by satisfaction of spatial restraints. J Mol Biol 1993, 234:779-8I5.

50. Do CB, Mahabhashyam MS, Brudno M, Batzoglou S: ProbCons: Probabilistic consistency-based multiple sequence alignment. Genome Res 2005, I 5:330-340.

5I. The PSIPRED Protein Structure Prediction Server [http:// bioinf.cs.ucl.ac.uk/psipred/]

52. McGuffin LJ, Bryson K, Jones DT: The PSIPRED protein structure prediction server. Bioinformatics 2000, 16:404-405.

53. Kabsch W, Sander C: Dictionary of protein secondary structure: pattern recognition of hydrogen-bonded and geometrical features. Biopolymers 1983, 22:2577-2637.

54. Bower MJ, Cohen FE, Dunbrack RL Jr: Prediction of protein sidechain rotamers from a backbone-dependent rotamer library: a new homology modeling tool. J Mol Biol 1997, 267: $1268-1282$.

55. Clark M, Cramer RD III, van Opdenbosch N: Validation of the general purpose Tripos $\mathbf{5 2}$ force field. J Comput Chem 1989, I0:982- I0I2.

56. Laskowski RA, MacArthur MW, Moss DS, Thornton JM: PROCHECK - a program to check the stereochemical quality of protein structures. J Appl Cryst 1993, 26:283-291.

57. The FIGENIX automated genomic annotation platform [http://www.up.univ-mrs.fr/evol/figenix/]

58. Gouret P, Vitiello V, Balandraud N, Gilles A, Pontarotti P, Danchin EG: FIGENIX: intelligent automation of genomic annotation: expertise integration in a new software platform. BMC Bioinformatics 2005, 6: 198.
59. Phylogenetic Analysis by Maximum Likelihood [http://aba cus.gene.ucl.ac.uk/software/paml.html]

60. Yang Z: PAML: a program package for phylogenetic analysis by maximum likelihood. Comput Appl Biosci 1997, I3:555-556.

61. Rozas J, Rozas R: DnaSP version 3: an integrated program for molecular population genetics and molecular evolution analysis. Bioinformatics 1999, I5: 174-175.

62. Yang Z: Likelihood ratio tests for detecting positive selection and application to primate lysozyme evolution. Mol Biol Evol 1998, 1 5:568-573.

63. Zhang J, Nielsen R, Yang Z: Evaluation of an improved branchsite likelihood method for detecting positive selection at the molecular level. Mol Biol Evol 2005, 22:2472-2479.

64. Tajima F: Statistical method for testing the neutral mutation hypothesis by DNA polymorphism. Genetics I989, I 23:585-595.

65. PyMol molecular graphic system [http://www.pymol.org]

66. The Single Nucleotide Polymorphism database [http:// www.ncbi.nlm.nih.gov/entrez/query.fcgi?db=Snp]

67. Fullerton SM, Bond J, Schneider JA, Hamilton B, Harding RM, Boyce AJ, Clegg JB: Polymorphism and divergence in the beta-globin replication origin initiation region. Mol Biol Evol 2000, I7:179-188.

68. Zhao Z, Jin L, Fu YX, Ramsay M, Jenkins T, Leskinen E, Pamilo P, Trexler M, Patthy L, Jorde LB, Ramos-Onsins S, Yu N, Li WH: Worldwide DNA sequence variation in a l0-kilobase noncoding region on human chromosome 22. Proc Natl Acad Sci USA 2000 , 97:। I354-11358

69. Zietkiewicz E, Yotova V, Jarnik M, Korab-Laskowska M, Kidd KK, Modiano D, Scozzari R, Stoneking M, Tishkoff S, Batzer M, Labuda D: Genetic structure of the ancestral population of modern humans. J Mol Evol 1998, 47:| 46-I55.

70. Harris $E E$, Hey J: $\mathbf{X}$ chromosome evidence for ancient human histories. Proc Natl Acad Sci USA 1999, 96:3320-3324.

71. Kaessmann H, Heissig F, von Haeseler A, Paabo S: DNA sequence variation in a non-coding region of low recombination on the human X chromosome. Nat Genet 1999, 22:78-8I.

Publish with Bio Med Central and every scientist can read your work free of charge

"BioMed Central will be the most significant development for disseminating the results of biomedical research in our lifetime. "

Sir Paul Nurse, Cancer Research UK

Your research papers will be:

- available free of charge to the entire biomedical community

- peer reviewed and published immediately upon acceptance

- cited in PubMed and archived on PubMed Central

- yours - you keep the copyright
BioMedcentral 